\title{
Inheritance of Resistance to Alternaria Leaf Blight in Muskmelons
}

\author{
George E. Boyhan ${ }^{1}$ and Joseph D. Norton ${ }^{2}$ \\ Department of Horticulture and Alabama Agricultural Experiment \\ Station, Auburn University, Auburn, AL 36849 \\ Additional index words. Alternaria cucumerina, Cucumis melo
}

\begin{abstract}
Muskmelon (Cucumis melo L.) breeding line AC-82-37-2 was identified as having resistance to alternaria leaf blight caused by Alternaria cucumerina (Ell. and Ev.) Elliot. An analysis of this resistance with a three-factor scaling test indicated that both additive and dominance effects were highly significant. The $x^{2}$ value indicated that there were epistatic effects as well. The six-factor scaling test revealed no significant dominance effect, but the additive and homozygote $\times$ heterozygote epistatic interaction effects were highly significant.
\end{abstract}

Disease is a major factor limiting the production of muskmelons in the southeastern United States, and alternaria leaf blight caused by Alternaria cucumerina is one of the most serious problems. This disease is particularly severe when periods of high rainfall and humidity occur during the midsummer growing season (Westcott, 1960). This study was conducted to determine sources of resistance to altemaria leaf blight and to determine the genetic basis for this resistance.

Various muskmelon cultivars, plant introductions, and germplasm releases reportedly have resistance to altemaria leaf blight. These include UF-G508, UF-G509, UF-G510, UFG511, and UF-G515 short-internode germplasm releases from the Univ. of Florida (Halsey, 1980); two plant introductions (PIs) from India, PI-164364 and PI-164756 (G. Sowell, personal communication); and the cultivar Purdue 44 (Ellis and Halliday, 1970; Westcott, 1960).

There exists evidence for several of $A$. cucumerina. Isolates from watermelon, for example, failed to infect cucumber (Crisan, 1976). Further, isolate QM 8578 is considered more virulent than QM 8575 (Orellana and Simmons, 1966). Sowell (1965) reported that QM 7448 is more virulent than AC-3.

Cultivars, lines, or PIs used in this study included AC-82-37, AC-82-37-2, PI 164756,

Received for publication 29 July 1991. Accepted for publication 11 May 1992. Ala. Agr. Expt. Sta. J. no. 11-913052. Special thanks are extended to Claude Thomas who supplied inoculum and Timothy $\mathrm{Ng}$ for his help in analyzing data. The cost of publishing this paper was defrayed in part by the payment of page charges. Under postal regulations, this paper therefore must be hereby marked advertisement solely to indicate this fact.

${ }^{1}$ Senior Research Associate.

${ }^{2}$ Professor.
UF-G511, Hale's Best, and PMR 6. Cultures of AC-3 isolate of A. cucumerina were obtained from Claude Thomas (Research Plant Pathologist, U.S. Dept. of Agriculture-Agriculture Research Service, U.S. Vegetable Laboratory, Charleston, S.C.) and refrigerated at $\approx 5 \mathrm{C}$ until inoculum was needed. Inoculum was increased on potato dextrose agar medium. Spores were rinsed from culture dishes and concentrations were adjusted to 15,000 spores/milliliter of water using a hemacytometer (Tuite, 1969). Spore suspensions were sprayed to runoff on 2-week-old seedlings that were incubated $48 \mathrm{~h}$ at $100 \%$ relative humidity and $25 \mathrm{C}$ in darkness. Screening for resistance to alternaria was conducted in the greenhouse at 20 to $35 \mathrm{C}$. Plants were visually rated on a 0 to 5 scale for disease severity 2 to 3 weeks after removal from the incubation chamber, where $0=$ no infection, $1=1 \%$ to $20 \%$ of leaf area infected, $2=21 \%$ to $40 \%$ infected, 3 $=41 \%$ to $60 \%$ infected, $4=61 \%$ to $80 \%$ infected, and $5=81 \%$ to $100 \%$ infected.

Parental lines were screened in the greenhouse in Fall 1982 using a completely ran-

Table 1. Disease rating of muskmelon lines inoculated with Alternaria cucumerina in greenhouse screening.

\begin{tabular}{lcc}
\hline \hline Entry & No. seedlings & Mean rating \\
\hline AC-82-37 & 34 & $1.2 \mathrm{a}^{\mathrm{y}}$ \\
AC-82-37-2 & 35 & $1.6 \mathrm{ab}$ \\
PI 164756 & 17 & $2.4 \mathrm{bc}$ \\
UF-G511 & 27 & $2.6 \mathrm{c}$ \\
Hale's Best & 9 & $3.0 \mathrm{~cd}$ \\
PMR 6 & 30 & $3.6 \mathrm{~d}$ \\
\hline
\end{tabular}

${ }^{2}$ Disease index: $0=0 \%$ infected, $1=1 \%$ to $20 \%$ of leaf area infected, $2=21 \%$ to $40 \%, 3=41 \%$ to $60 \%, 4=61 \%$ to $80 \%, 5=81 \%$ to $100 \%$. ${ }^{\mathrm{r}}$ Means followed by the same letter are not significantly different $(P=0.01)$ according to Tukey's HSD test. 
Table 2. Generation means and distributions of resistant and susceptible parents and progeny to alternaria leaf blight.

\begin{tabular}{|c|c|c|c|c|c|c|c|c|}
\hline \multirow[b]{2}{*}{ Generation } & \multirow[b]{2}{*}{ Mean } & \multirow{2}{*}{$\begin{array}{l}\text { Total no. } \\
\text { seedlings }\end{array}$} & \multicolumn{6}{|c|}{ Classes $^{2}$} \\
\hline & & & 0 & 1 & 2 & 3 & 4 & 5 \\
\hline P1 (PMR 6) & $3.6 \pm 0.9$ & 30 & $\cdots$ & $\cdots$ & 4 & 10 & 11 & 5 \\
\hline P2 (AC-82-37-2) & $1.6 \pm 0.9$ & 35 & 1 & 18 & 11 & 4 & $\cdots$ & 1 \\
\hline $\mathrm{F} 1$ & $2.6 \pm 0.6$ & 119 & -- & 3 & 43 & 72 & $\ldots$ & 1 \\
\hline $\mathrm{F} 2$ & $2.5 \pm 1.4$ & 170 & 7 & 43 & 36 & 40 & 27 & 17 \\
\hline BCP1 & $3.4 \pm 1.0$ & 177 & 0 & 6 & 23 & 69 & 47 & 32 \\
\hline $\mathrm{BCP} 2$ & $1.4 \pm 1.2$ & 172 & 35 & 79 & 38 & 10 & 1 & 9 \\
\hline
\end{tabular}

${ }^{2}$ Disease index: $0=0 \%$ infected, $1=1 \%$ to $20 \%$ of leaf area infected, $2=21 \%$ to $40 \%, 3=41 \%$ to $60 \%, 4=61 \%$ to $80 \%, 5=81 \%$ to $100 \%$.

Table 3. Estimates of gene effects in a threeparameter model. ${ }^{2}$

\begin{tabular}{lcc}
\hline \hline Parameter & Effect & SE \\
\hline Mean & $62.64^{* *}$ & 2.67 \\
Additive & $39.36^{* *}$ & 2.77 \\
Dominance & $-7.52^{* *}$ & 3.34 \\
$\chi^{2}(\mathrm{df}=3)$ & $25.79^{* *}$ & \\
\hline
\end{tabular}

${ }^{2}$ Effects and SE are computed with transformed data $[\arcsin (\mathbf{x} / 5) \times 100]$.

** Significant at $P=0.01$.

domized design and analyzed using Tukey's HSD test. Crosses were made between the selected resistant breeding line (AC-82-372) and the susceptible cultivar (PMR 6) in the greenhouse and in the growth chamber. A single $F_{1}$ plant was selfed to produce an $\mathrm{F}_{2}$ generation. Further, other single plants of the $F_{1}$ generation were backcrossed to one plant each of the resistant and susceptible parents. The $\mathrm{F}_{1}, \mathrm{~F}_{2}$, and $\mathrm{BC}$ generations were then screened in Fall 1983 under greenhouse conditions using a completely randomized design.

The three-factor and six-factor scaling tests (Mather and Jinks, 1977) were conducted on data transformed by dividing each datum by five, computing the arcsin, and multiplying by 100 . The broad-sense and narrow-sense heritabilities were calculated as $\mathrm{V}_{\mathrm{G}} / \mathrm{V}_{\mathrm{p}}$, and $\mathrm{V}_{\mathrm{A}} / \mathrm{V}_{\mathrm{P}}$, respectively, where $\mathrm{V}_{\mathrm{G}}$ is genotypic variance, $\mathrm{V}_{\mathrm{P}}$ is phenotypic variance, and $\mathrm{V}_{\mathrm{A}}$ is additive variance (Simmonds, 1979).

Breeding line AC-82-37-2 is the open-pollinated progeny of AC-82-37 grown in isolation. AC-82-37 is the result of an interspecific cross between C. melo (PI 140471) and C. metuliferous E. Mey (Norton, 1969), which was backcrossed to Chilton for five generations and subsequently grown in isolation. AC-82-37-2 showed higher resistance than UF-G511, Hale's Best, or PMR-6 (Table 1). Lesions were slow to develop and remained small on the leaves of AC-82-37-2. This characteristic was first noted in the field in 1982, and based on this informal observation, this line was included in greenhouse tests. In contrast, the lesions on the susceptible PMR 6 tended to coalesce, blighting entire areas of the leaf and often resulting in death of the entire plant.

Although the means and distributions of progeny suggest that much of the variation can be explained by a simple one- or twogene model, these models do not fully describe the resistant-susceptible interaction (Table 2). Therefore, three-factor and sixfactor scaling tests were used to describe the quantitative character of the data (Table 3; Mather and Jinks, 1977; Ng, 1990). The scaling tests were conducted with transformed data to prevent nonindependence (Mather and Jinks, 1977). The transformation chosen $[\mathrm{x}=(\arcsin (\mathrm{x} / 5) \times 100]$ assured that the mean, additive, and dominance

Table 4. Estimates of gene effects in a six-parameter model. ${ }^{2}$

\begin{tabular}{lr}
\hline \hline Parameter & \multicolumn{1}{c}{ Effect } \\
\hline [m] Midparent (between AA and aa) & $68.71 \pm 15.60^{* *}$ \\
[d] Difference of AA and aa from midparent value & $25.99 \pm 4.01^{* *}$ \\
[h] Difference of Aa from midparent value & $-24.21 \pm 36.97^{\mathrm{NS}}$ \\
[i] Homozygote $\times$ homozygote interaction & $-7.58 \pm 15.07^{\mathrm{NS}}$ \\
[j] Homozygote $\times$ heterozygote interaction & $54.61 \pm 11.25^{* *}$ \\
[i] Heterozygote $\times$ heterozygote interaction & $11.14 \pm 22.05^{\mathrm{NS}}$ \\
\hline
\end{tabular}

${ }^{2}$ Effects are computed with transformed data $[\arcsin (\mathbf{x} / 5) \times 100]$.

Ns,**Nonsignificant or significant at $P=0.01$.

values were significantly different from 0 and also resulted in the lowest $\mathrm{X}^{2}$ value possible. The mean, additive, and dominance effects were highly significant based on the threefactor scaling test, indicating both an additive and dominance component to inheritance (Table 3). Since the $\mathrm{X}^{2}$ was also highly significant, this model was inadequate to completely describe the interaction, presumably because of an epistatic effect.

The six-factor scaling test confirmed the additive [d] portion of inheritance, but the dominance [h] portion was no longer significant (Table 4). Further, the heterozygote $x$ homozygote epistatic interaction was highly significant. The broad-sense and narrow-sense heritabilities were calculated as 0.57 and 0.45 , respectively. The high additive component, coupled with the relatively high heritability values, indicates that a breeding program relying on pedigree and backcross methods would result in progress toward breeding resistance to alternaria leaf blight in muskmelon.

\section{Literature Cited}

Crisan, A. 1976. Aspects of the spread, biology and control of Alternaria species parasitic on vegetables in the Cluj-Napoca District. Contributii Botanice p. 11-22.

Ellis, M.B and P. Holliday. 1970. AIternaria cucumerina . Commonwealth Mycological Inst. Descriptions Pathogenic Fungi Bacteria. set 25 no. 244.

Halsey, L.H. 1980. U.F. G508, G509, G510, G511, and G515 muskmelon breeding lines. HortScience 15:538.

Mather, K. and J.L. Jinks. 1977. Introduction to biometrical genetics. Cornell Univ. Press, Ithaca, N.Y.

Ng, T.J. 1990. Generation means analysis by microcomputer. HortScience 25:363.

Norton, J.D. 1969. Cantaloupe breeding. Biennial Rpt. Veg. Breeding Southern United States, Hawaii, and Puerto Rico. U.S. Veg. Breeding Lab. p. 53.

Orellana, R.G. and E.G. Simmons. 1966. Alternaria blight of guar in the United States. Mycopathologia et Mycologia Applicata 29:129133.

Simmonds, N.W. 1979. Principles of crop improvement. Longman, N.Y.

Simmons, E.G. 1967. Typification of Alternaria, Stemphylium and Ulocaldium. Mycologia 59:6792.

Sowell, G. 1965. Alternaria leafspot of guar. Plant Dis. Rptr. 49:605-607.

Tuite, J. 1969. Plant pathological methods. Fungi and bacteria. Burgess Publishing Co., Minneapolis.

Westcott, C. 1960. Plant disease handbook. 2nd ed. D. Van Nostrand Co., Princeton, N.J. 